\title{
Shifting Cultivation: A Cautionary Note
}

\author{
Lindsay Falvey
}

\section{Summary:}

Shifting cultivation is a long established agricultural practice that continues to be practiced less each decade. Nevertheless, it remains important for those who sustain themselves from such food production systems, and as a viable means of integrating some modern concerns. Where populations are not rising substantially and no alternative agricultural systems have been proven, these systems continue to offer a degree of national security from further urban immigration as well as watershed and forest management and as carbon sinks. As shifting cultivation is practiced in highland regions, and the majority of such cultivators and highlands are in the Asian region, the subject remains of historical and current importance to Asia. This paper argues that respect for the cultivators, their system and the environment should act as a caution to those engaged in development that might impact on shifting cultivation.

In agri-history, civilization is seen as dependent on the arising of the first agricultural settlements (Falvey, 2013). Those who then treat history as a phenomenon of urban power can easily assume that rural areas are populated by peasant agriculturists. Perhaps it is this viewpoint that creates misunderstandings about shifting cultivation, which is also known as swidden agriculture or jhum. This can be comprehended when it is seen how convenient it is to consider a smooth transition from hunter-gatherers to pastoralists to farmers to managed forests to conservation areas. Diverse literature describes confrontations between pastoralists and settled agriculturists (for example, Genesis 4: 1-15), which the agriculturists win since it is their progeny that wrote the histories. Yet this progressive assumption is not supported by history as illustrated in Figure 1, which suggests overlapping of the above forms of human interaction with the environment. However, habitual views continue in Asia today in attempts to settle seminomadic Mongolian herders, for example. 


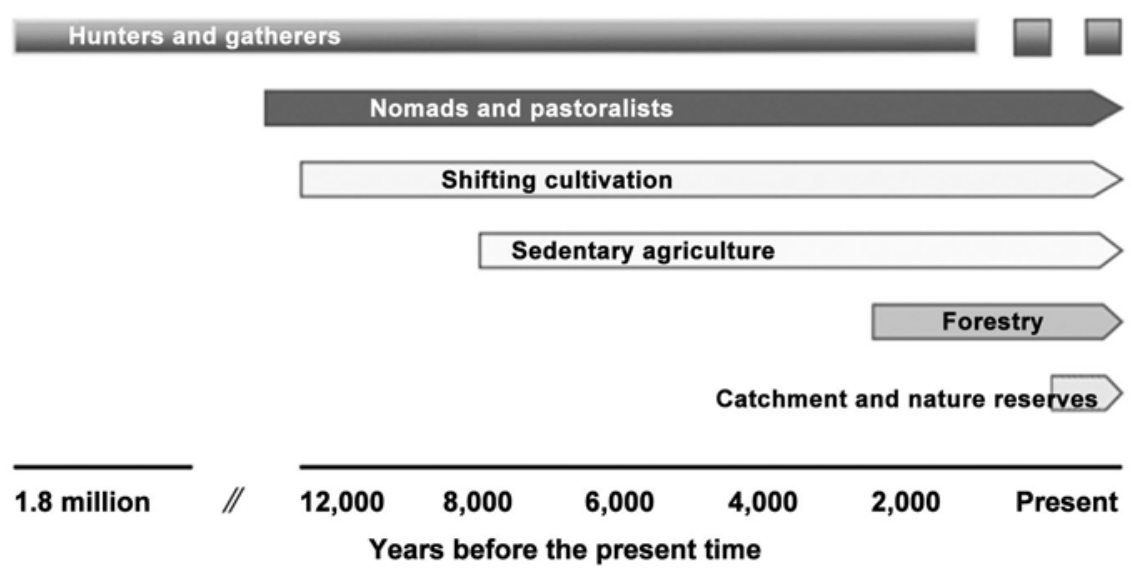

Figure 1. A Schematic Summary of Land use over Time

With a rising awareness of environmental management being a central function of both animal and plant agriculture, unchallenged assumptions of the primitive nature of nomadic pastoralism are increasingly misplaced. Traditional rangeland management of such groups has been shown to be more sustainable on traditional areas than when those same areas have been fenced (Falvey, 2015), mainly because land is protected by socially-embedded usage-right systems that account for seasonal variations. The same misconceptions apply to shifting cultivation that traditionally managed long forest fallows while human population density did not demand shortened cycles.

Having evolved over 12,000 years to today include agroforestry, animal husbandry, forest management, fallow management, horticulture, food-grain cropping and cash cropping in integrated systems (Spencer, 1966), shifting cultivation retains its potentially high sustainability compared to much technologically-dependent farming. Against such an observation, it I still common to see the practice referred to as 'slash-and-burn' as in the left-hand diagram in Figure 2 (Dubois, 1990). A more correct diagram would be that on the right-hand side in which the long length of forest-fallow is clear. Negative misinformation also includes the assigning excessive blame for carbon emissions (Griffiths, 2008) by ignoring the sequestration from regeneration of secondary forest and the information that industrial agriculture is the major source of emissions (FAO, UNDP, UNEP, 2008). Seen in this light, shifting cultivation is one more poorly understood traditional farming system. These are important matters for Asia. 


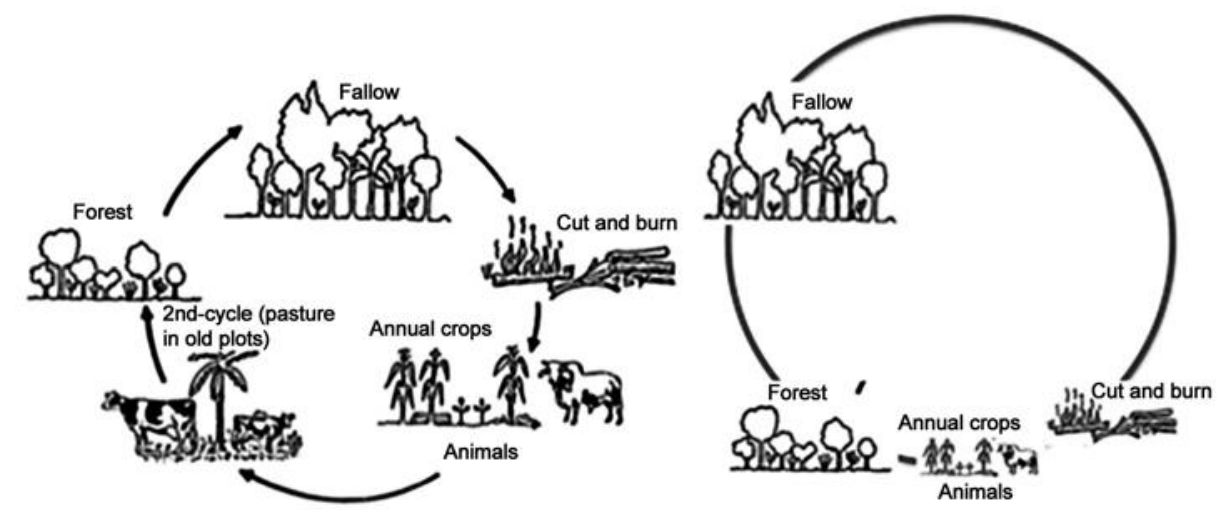

Figure 3. The Conventional (left) Shifting Cultivation Model and its Correction (right)

\section{Importance in Asia}

As a poorly studied form of food production, the numbers of persons engaged and supported by shifting cultivation are often little more than guesses. They may number more than 300 million (Kleinman et al., 1996) across 40 countries (Mertz, 2009), mainly being confined to highlands. The total population is significant when it is considered that the majority are said to be in Asia, and in particular Southeast Asia - simply because the region contains most of the world's highlands (Huddlestonetal,2003) - see Figure 3. However, illustrating the poor state of information, another estimate suggests that there may be only 14 to 34 million in highland Southeast Asia (Mertz et al., 2009). Mountainous regions, as recognized in Chapter 13, Agenda 21 of the 1992 United Nations' Earth Summit, are claimed to support 12 percent of the world's population (as per the 700 million population estimate which may contain lowlanders dependent on highlands). Perhaps the lack of clear information can be taken as a signal of this farming system's ultimate demise; on the other hand, it may be that it also represents a fall-back for those marginalized by 'civilized' regions. 


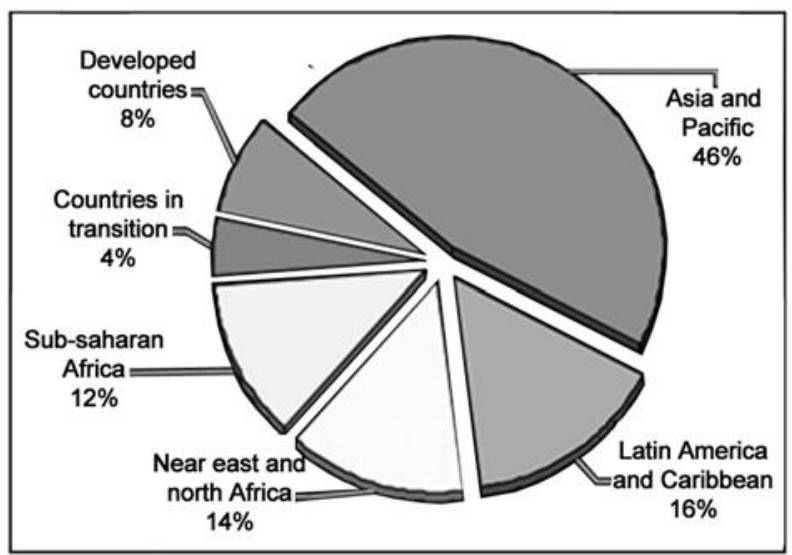

Figure 3. Most of the World's Highlands are in Asia (von Braun, 2005).

Urban centres are overwhelmingly located in lowlands from which perspective those in the highlands practicing shifting cultivation are seen as exploiting resources of water, biodiversity and landscape. Another perspective may be that highlanders, valuing their freedom from the demands of civilization, have been increasingly ostracized as their populations, like their urbanized neighbours, have risen, giving rise to environmental trade-offs when forest cycles are shortened. This is akin to the trade-offs inherent in the intensification that is the imperative for all agriculture; and in that comparison, shifting cultivation is not the major offender.

Perhaps shifting cultivation is better conceived as a form of rotational agriculture (Kerkhoff and Sharma, 2006), a prescient suggestion that today acknowledges the integration of agricultural and forestry as well as fallow management practices. However, most such suggestions arise from within a sedentary worldview that assumes routine land tenure as distinct from the seasonally-adjusted and socially-managed usage rights that have evolved in shifting cultivation. Those systems are breaking down but so long as highlands can provide fresh water for domestic and industrial uses and absorb some lowland carbon emissions, agroforestry and community forest approaches seem to provide the best overall view of highland agriculture.

The region where most shifting cultivation is practiced is known as the Southeast Asian Massif and represents areas higher than $300 \mathrm{~m}$ from Bangladesh to Vietnam as indicated in Figure 4 (Michaud, 1997), and with the Himalayan massif has also been called Zomia (van Schendel, 2002). Interrelations and commonalities of cultural accoutrements led to the postulate that these shifting cultivators are progeny of refugees from lowland regions (Scott, 2009). 


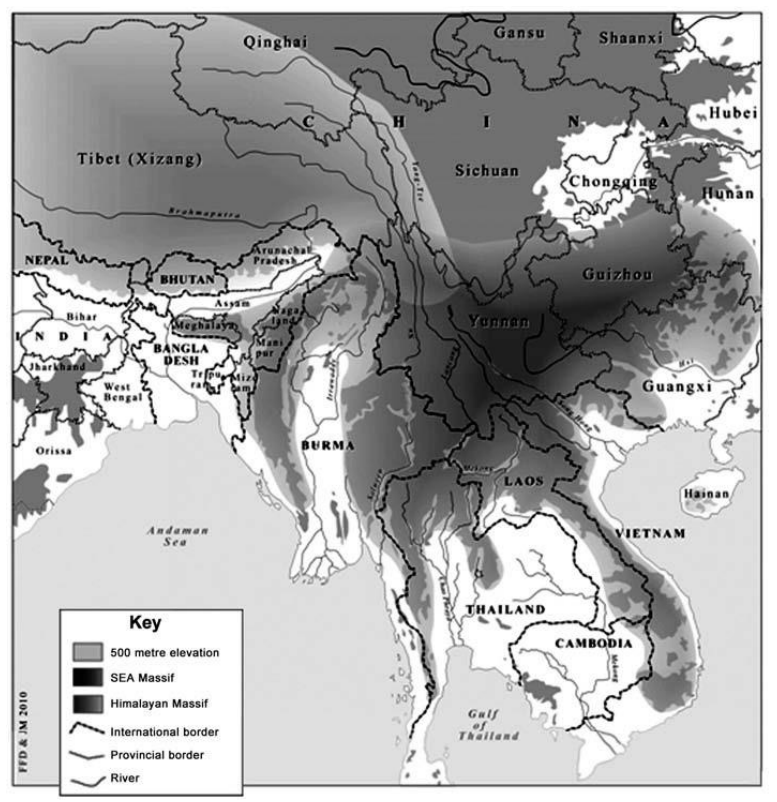

Figure 4. The Southeast Asian Highlands

\section{Development}

Diverse although uncoordinated research has been conducted across the region over at least the past six decades, beginning with anthropological and geographical studies, which were succeeded by agriculturally-oriented development research about 40 years ago. Thereafter, the majority of activities have been development projects, occasionally with some applied research. Thailand as a US ally during the Vietnam conflict period was a major beneficiary, initially with a focus on opium replacement. The ultimate goal was to sedentarize highland populations around cash cropping, to secure borders and to replace shifting cultivation by re-afforestation (Tapp, 1979). Developments resulted in major changes, including; improved living conditions, reduced rites including animal sacrifices (Falvey, 1980), changing swine from fat to pork production (Visitpanich and Falvey, 1981) and replacing corn-cob tea with the new industry of coffee (Angkasith and Warrit,1999).

A project with which I was associated in 1970s, the Thai-Australia Highland Agricultural Project (Falvey, 2015), focussed on research aimed at working within the traditional social systems as far as possible. Its immediate effects were minimal, but significant in the longer term, which indicates the need for constancy to integrate social and technological themes. This has been one reason for the particular success of the Royal Projects across the Thai highlands. 
From such patchy experience, we may now be approaching an understanding that the traditional agricultural practice known as shifting cultivation should not be seen as 'a backward type of agricultural practice ... [and] ... of culture', as it was once described by FAO (1957). Rather it can been see, as FAO now acknowledges, as an insightful environmental management system that offers benefits ranging from watershed and wildlife management to carbon-offsets. As with much in traditional agriculture, the lessons are:

- avoid untested replacement of viable systems with modern ones;

- work within traditional systems for their improvement where possible, and

- acknowledge that wherever an existing system feeds it population that the human, food and monetary costs of displacing those people should be considered before any action is taken.

\section{References}

Angkasith, P. and Warrit, B. (1999) Highland Arabica Coffee Production, Mingmoeng Publishing, Chiang Mai.

Dubois, J. (1990) Secondary forests as a land use resource in frontier zones of Amazonia, in A. Anderson (ed.) Alternatives to Deforestation, Columbia University Press, New York

Falvey, J. L.(1980) Cattle and Sheep in Northern Thailand, Thai-Australia Highland Agricultural Project, Chiang Mai.

Falvey, L. (2013) 'Musing on Agri-history', Asian Journal of Agri-History 17(2): 183-191.

Falvey, L. (2015) Sustainable Development in the Thai highlands: The experience of the Thai-Australian Development Project', First International Highland Conference, Chiang Mai University, Chiang Mai, January.

FAO (1957) Shifting cultivation, Unasylva 11: 9-11

FAO, UNDP, UNEP(2008) Collaborative Programme on Reducing Emissions from Deforestation and Forest Degradation in Developing Countries, Rome.

Genesis 4: 1-15. The Bible 
Griffiths, T. (2008) Seeing REDD? Forests, Climate Change Mitigation and the Rights of Indigenous Peoples and Local Communities, Update for the 14th session of the Conference of the Parties to the United Nations' Framework Commission on Climate Change, Poznan, Poland.

Huddleston, B., Ataman, E. and d'Ostiani, L. (2003) Towards a GIS-based Analysis of Mountain Environments and Populations, Environment and Natural Resources Working Paper No. 10, Food and Agricultural Organization of the United Nations, Rome

Kerkhoff, E. and Sharma, E. (2006) Debating Shifting Cultivation in the Eastern Himalayas: Farmers' Innovations as Lessons for Policy, International Centre for Integrated Mountain Development, Kathmandu.

Mertz, O., Heinimann, A., Rerkasem, K., Thiha, Dressler, W., Pham, V. C., Vu, K. C., Schmidt-Vogt, D., Colfer, C. J. P., Epprecht, M. and Paddoch, C. (2009a) Who Counts? Demography of Swidden Cultivators in Southeast Asia. Human Ecology 37, pp218-289.

Michaud, J. (2010) Zomia and Beyond, Journal of Global History 5(2) 187-214.

Scott, J. (2009) The Art of Not Being Governed: An Anarchist History of Upland Southeast Asia, Yale University Press, New Haven.

Spencer, J. E. (1966) Shifting Cultivation in Southeastern Asia, University of California Press, Berkeley, CA

Tapp, N. (1979) Thailand Government Policy Towards the Hill-dwelling Minority Peoples in the North of Thailand, 1959-1976, Master's Thesis, School of African and Oriental Studies, London.

van Schendel, W. (2002) Geographies of Knowing, Geographies of Ignorance. Environment and Planning, Society and Space 20: 647-668.

Visitpanich, T. and Falvey, J. L. (1981) Nutrition of Highland Swine. Thai Journal of Agricultural Science 14: 123-128.

von Braun, J. (2005) Agricultural Development in the Highlands', International Food Policy Research Institute presentation, 24 July, Lhasa, Tibet, China. 